\title{
Nursing measure in Intensive Care Unit: evidence about the Nursing Activities Score
}

\author{
Dimensionamento de enfermagem em Unidade de Terapia Intensiva: evidências sobre o \\ Nursing Activities Score
}

\section{Dimensionamiento de enfermería en Unidad de Cuidados Intensivos: evidencias acerca del Nursing Activities Score}

Patrícia Cabral Ferreira ${ }^{1}$, Regimar Carla Machado ${ }^{1}$, Allyne Fortes Vitor ${ }^{1}$, Ana Luisa Brandão de Carvalho Lira ${ }^{1}$, Quênia Camille Soares Martins ${ }^{1}$

This study aimed to identify the use of the Nursing Activities Score to measure the nursing workload in Intensive Care Unit. This is a review conducted in the databases SCOPUS, CINAHL, PUBMED and LILACS in June 2013, including 18 articles that have been published since 2002. The studies included are concentrated in Brazil; the average of Nursing Activities Score was bigger than $50 \%$, reflecting an inconsistency with the measure recommended by the Brazilian Ministry of Health. The Nursing Activities Score was the most appropriate instrument to estimate the amount of nurses in the Intensive Care Unit.; the correlation between the Nursing Activities Score and the demographic and clinical variables are not well defined in the research results, showing variations in the studies analyzed. The Nursing Activities Score is a relatively new tool, which shows a great potential for expansion due to the good results obtained with its use so far.

Descriptors: Nursing; Intensive Care Units; Workload.

Objetivou-se identificar a utilização do Nursing Activities Score para dimensionar a carga de trabalho de enfermagem em Unidade de Terapia Intensiva. Revisão realizada nas bases de dados SCOPUS, CINAHL, PUBMED e LILACS, em junho de 2013, sendo incluídos 18 artigos publicados a partir de 2002. Os estudos concentram-se no Brasil; a média de Nursing Activities Score foi maior que 50\%, refletindo incoerência com o dimensionamento preconizado pelo Ministério da Saúde do Brasil. O Nursing Activities Score foi o instrumento mais adequado para estimar o quantitativo de profissionais de enfermagem em Unidade de Terapia Intensiva; a correlação do Nursing Activities Score com variáveis demográficas e clínicas ainda não está bem definida nos resultados das pesquisas, apresentando variações nos estudos analisados. 0 Nursing Activities Score é um instrumento relativamente novo, o qual apresenta grande potencial de expansão em função dos resultados eficazes encontrados com seu uso até o momento.

Descritores: Enfermagem; Unidades de Terapia Intensiva; Carga de Trabalho.

El objetivo fue identificar el uso del Nursing Activities Score para dimensionar la carga de trabajo de enfermería en Unidad de Cuidados Intensivos. Revisión realizada en las bases de datos SCOPUS, CINAHL, PubMed y LILACS, en junio de 2013, en que se incluyeron 18 artículos publicados desde 2002. Los estudios se concentran en el Brasil; los medios Nursing Activities Score fue mayor que 50\%, reflejando incompatibilidad con el recomendado por el Ministerio de la Salud brasileño. El Nursing Activities Score fue el instrumento más adecuado para estimar la cantidad de personal de enfermería en Unidad de Cuidados Intensivos; la correlación del Nursing Activities Score con variables demográficas y clínicas no está bien definida en los resultados de búsqueda, presentándose variaciones en los estudios analizados. El Nursing Activities Score es una herramienta relativamente nueva que presenta gran potencial de expansión por los resultados eficaces obtenidos con su uso hasta el momento.

Descriptores: Enfermería; Unidades de Cuidados Intensivos; Carga de Trabajo.

${ }^{1}$ Universidade Federal do Rio Grande do Norte. Natal, RN, Brazil.

Corresponding author: Regimar Carla Machado

Rua Manoel Lele, 145/16, Ponta Negra, CEP: 59090-510. Natal, RN, Brazil. E-mail: regimarmachado@gmail.com 


\section{Introduction}

Intensive Care Units are hospital departments that attend severe or risk patients who require health care in an uninterrupted way, joining specific technological equipment and specialized human resources ${ }^{(1)}$. Health care activities developed in these units are considered complex and require high technical and scientific competence, since the established behaviors and the decision making are directly related to people's life and death. Thus, it becomes essential to provide skilled nursing professionals who are adequately trained to provide care with quality and safety to patients ${ }^{(2)}$.

The staff measure is a systematic process that aims at predicting the quantity and quality by category (nurse, nursing technician and nursing assistant) needed to meet, directly or indirectly, the clients' needs for nursing care $^{(3)}$.

When it comes to the Intensive Care Unit, the measure of the nursing staff must be conducted in accordance with the patient's assistance needs, but also taking into consideration the financial aspect, since it is a unit with high cost within health care institutions. An oversized team involves high cost, while a small team tends to cause a decrease in the efficiency of care, prolonged hospitalization, increase in morbidity/mortality and in the cost of patients' treatment ${ }^{(4)}$.

Given the growing need to obtain an assessment of the qualitative and quantitative adequacy of the nursing staff concerning the workload, instruments were developed to classify patients in relation to their health needs, as well as to quantify the time spent by these care professionals in the provision of care $^{(5)}$.

Among the existing instruments, the Therapeutic Intervention Scoring System (TISS) is described in the international literature as one of the pioneers for classifying critically ill patients, as well as for estimating and evaluating the workload of the nursing staff in Intensive Care Units. Its methodology is based on the quantification of therapeutic interventions, accor- ding to the degree of complexity, degree of invasiveness and the time spent by the nursing staff to implement specific procedures with patients ${ }^{(6)}$.

In its first version, developed in 1974, the Therapeutic Intervention Scoring System consisted of a total of 57 therapeutic interventions ${ }^{(6)}$. In 1983, the index was revised and updated to 76 items (TISS-76) ${ }^{(7)}$. This version, although widely used, was simplified in 1996 through the grouping of related items, reducing to 28 the number of therapeutic interventions assessed. TISS-28, as it is known, became the most accepted and used version in Intensive Care Units ${ }^{(8)}$.

Despite the importance of TISS-28, its practical application has shown structural failure to the full measure of nursing workload, as it did not include the activities related to patients' indirect care, such as organizational, family support and administrative tasks. Thus, in order to overcome the shortcomings identified and portray more accurately the activities and workload of nurses in intensive care units, in 2003 a new instrument was elaborated, the Nursing Activities Score ${ }^{(9)}$.

The Nursing Activities Score is a tool that punctuates care needs required by patients within 24 hours, based on the quantification of interventions during this period. It is composed of seven categories or domains (Nursing Activities, Ventilatory Support, Cardiovascular Support, Renal Support, Neurological Support, Metabolic Support and Specific Interventions), which are composed of sub-subdomains or even subdivided into sections, in a total of 23. To each item it is assigned a score whose final score expresses the percentage of time spent by the nursing staff in direct patient care, ranging from 0 to $176.8 \%{ }^{(9)}$.

In this sense, the production of knowledge on the use of the Nursing Activities Score to measure the nursing workload in Intensive Care Units may improve the allocation of nursing staff and, consequently, the assistance provided to inpatients. Given this context, there is a need to investigate: what is the scientific literature on the use of the Nursing Activities Score to measure nursing workload in Intensive Care Units? 
Thus, this study aimed to identify in the scientific literature the use of the Nursing Activities Score to measure the nursing workload in Intensive Care Units.

\section{Method}

This is an integrative literature review, which is considered a comprehensive methodological approach concerning revisions, allowing the inclusion of experimental and non-experimental studies for a complete understanding of the analyzed phenomenon ${ }^{(10)}$. Five steps led this integrative review: 1) identification of the problem; 2) literature search; 3) data evaluation; 4) data analysis; and 5) presentation of the results ${ }^{(10)}$. To fulfill them, initially a search protocol was built, which contained: goal, guiding questions, search strategies (databases used, descriptors and intersections), selection of studies (inclusion and exclusion criteria) and strategy for data collection of the studies (data collection instrument).

The guiding question of the research was: what is the scientific literature about the use of the Nursing Activities Score to measure the nursing workload in Intensive Care Units?

Data collection was conducted during June and July 2013, in the databases: SCOPUS, CINAHL (Cumulative Index to Nursing and Allied Health Literature), PUBMED (National Library of Medicine and National Institutes of Health) and LILACS (LatinAmerican and Caribbean System on Health Sciences Information) using controlled descriptors, according to the classification of Health Sciences descriptors (DeCS): Nursing, Intensive Care Unit and Workload; as well as the MESH (Medical Subject Headings): Nursing, Intensive Care Units and Workload. The databases were accessed simultaneously by two researchers on different computers in order to ensure selection of the highest number of productions for the research.

The inclusion criteria were: original articles available in full published since 2002, year of creation of the Nursing Activities Score, which deal with the selected topic in Portuguese, English or Spanish, regardless of searching method used. One excluded dissertations, theses, editorials, notes to the editor, opinions of experts, publications that did not fit the established time frame and studies that did not answer the research question. Studies found in more than one database were considered only once.

From data collection, through the intersections of descriptors, the following results were found: Nursing AND Intensive Care Units AND Workload $($ SCOPUS $=2,291 ;$ LILACS $=27 ;$ CINAHL $=1,548$; and PUBMED = 7); Nursing AND Intensive Care Units (SCOPUS $=44,751 ;$ LILACS $=575$, CINAHL $=7,333$; and PUBMED = 50); Nursing AND Workload (SCOPUS = 12,758; LILACS $=84$, CINAHL $=18,015$; and PUBMED = 59); and Intensive Care Units AND Workload (SCOPUS $=18,569 ;$ LILACS $=27 ;$ CINAHL $=1,667 ;$ and PUBMED $=28$ ).

The initial sample consisted of 21 articles, 12 from SCOPUS, five from LILACS and four from CINAHL. Out of these studies, one described the development of the instrument Nursing Activities Score ${ }^{(9)}$ and two dealt exclusively with the translation and validation of the Nursing Activities Score for Portuguese ${ }^{(11)}$ and Spanish ${ }^{(12)}$, which were excluded from the final analysis. Thus, the final sample consisted of 18 articles.

Aiming to answer the research question, an instrument was elaborated to collect the following information: reference of the article; country of origin; goals and design of the study; and results of the application of the Nursing Activities Score in adult Intensive Care Units. This instrument was constructed based on another already validated, aiming to ensure that all the relevant data were extracted, to minimize the risk of errors in the transcription, to ensure accuracy in checking the information and to serve as a record ${ }^{(13)}$.

The results were presented descriptively and by means of a summary table with the following items: author, year, country of origin, sample, average of Nursing Activities Score and variation of the Nursing Activities Score. The articles analyzed were 
also grouped by thematic area, namely: average of Nursing Activities Score; number of professionals according to the Nursing Activities Score and to what is recommended by law; comparison of the measure Nursing Activities Score with other instruments of measure of nursing workload; and the correlation between the Nursing Activities Score with demographic and clinical variables.

\section{Results}

After systematic analysis of 18 selected scientific publications, the results were divided into two pillars: initially, one presents the characteristics of the studies found concerning the country of origin of the publication, year and journals of publication and research method (Figure 1); then one highlights the theoretical issues presented by the studies, emphasizing the use of the Nursing Activities Score to measure the nursing workload in adult Intensive Care Units.

\section{Characterization of the studies selected}

The studies developed about the Nursing Activities Score were concentrated in Brazil, totaling 16 productions (88.8\%), followed by Spain and Norway, with a production of $5.5 \%$, respectively.

The publication of the studies about the implementation of the Nursing Activities Score became a reality from 2006 on and kept at least two publications in the following years. The articles were developed in large hospitals, located mostly in big urban centers in the countries of origin, and there is a balance between public (55.5\%) and private institutions (44.5\%).

Concerning the journals of publication, one realizes that there is a distribution of journals in different areas of nursing, with a predominance of Acta Paulista de Enfermagem (28\%), in second the Intensive and Critical Care Nursing and the Revista da Escola de Enfermagem da USP with 22\% each, followed by the Revista Latino-Americana de Enfermagem, Revista Brasileira de Enfermagem, Revista Ciência, Cuidado e Saúde, Texto \& Contexto Enfermagem and Enfermagem Intensiva, with one production each. The predominant method was descriptive and exploratory with a quantitative approach.

\section{Practical application of the Nursing Activities Score}

Concerning the themes of the articles, all of them presented in their scope the verification of the average Nursing Activities Score. However, eight articles tried to associate the results of the Nursing Activities Score with indices of disease severity across the scale Simplified Acute Physiologic Score II and the organ dysfunction index "Logistic Organ Dysfunction System"; five articles tried to compare the Nursing Activities Score with other instruments for measuring nursing workload, such as the Therapeutic Intervention Scoring System-28 (TISS28) and the Nine Equivalents of Nursing Manpower Use Score; three articles aimed to compare the needs of nursing workload among specific populations such as the elderly and adults; three studies evaluated the applications of the Nursing Activities Score in specialized units, Cardiac and neurological Intensive Care Unit; one tried to analyze the performance of the Nursing Activities Score to measure the prospective nursing workload and to compare the values of the Nursing Activities Score obtained in the prospective application; and the others to calculate the need of nursing workload through the Nursing Activities Score.

The average Nursing Activities Score found was higher than $50 \%$ in all the studies reviewed. About $60 \%$ of the studies had an average Nursing Activities score between 60 and 70\% (overall average of $65.5 \%$ ). One highlights four studies that showed Nursing Activities Score higher than 70\%, as shown in Figure 1. 


\begin{tabular}{|c|c|c|c|c|}
\hline Authors/year & $\begin{array}{l}\text { Country } \\
\text { of origin }\end{array}$ & $\begin{array}{c}\text { Sample } \\
\text { (Patients) }\end{array}$ & $\begin{array}{l}\text { Average of Nursing } \\
\text { Activities Score (\%) }\end{array}$ & $\begin{array}{l}\text { Variation in the Nursing Activities } \\
\text { Score (minimum-maximum \%) }\end{array}$ \\
\hline $\begin{array}{l}\text { Adell AB, Campos RA, Bou MY, Bellmunt JQ, } \\
\text { García CG, Canuto MS et al. } 2006\end{array}$ & Spain & 350 & 50.4 & 29.7 to 84.5 \\
\hline $\begin{array}{l}\text { Ciampone JT, Gonçalves LA, Maia FOM, } \\
\text { Padilha KG. } 2006\end{array}$ & Brazil & 50 & 65.5 & 47.6 to 82.4 \\
\hline $\begin{array}{l}\text { Gonçalves LA, Garcia PC, Toffoleto MC, } \\
\text { Telles SC, Padilha KG. } 2006\end{array}$ & Brazil & 50 & 65.5 & 47.6 to 82.4 \\
\hline Gonçalves LA, Padilha KG. 2007 & Brazil & 214 & 69.9 & 54.3 to 122.5 \\
\hline Conishi RM, Gaidzinski RR. 2007 & Brazil & 33 & 65.5 & 22.3 to 127.9 \\
\hline $\begin{array}{l}\text { Padilha KG, Sousa RMC, Queijo AF, Mendes } \\
\text { AM, Miranda DR. } 2008\end{array}$ & Brazil & 200 & 67.2 & 54.3 to 107.2 \\
\hline $\begin{array}{l}\text { Sousa CR, Gonçalves LA, Toffoleto MC, Leão } \\
\text { K, Padilha KG. } 2008\end{array}$ & Brazil & 71 & 72.9 & 54.0 to 110.0 \\
\hline Ducci AJ, Padilha KG. 2008 & Brazil & 104 & $\begin{array}{c}\text { Prospective: } 59.8 \\
\text { Retrospective: } 52.7\end{array}$ & $\begin{array}{l}\text { Prospective: } 34.1 \text { to } 94.4 \\
\text { Retrospective: } 32.2 \text { to } 75.2\end{array}$ \\
\hline Ducci AJ, Zanei SSV, Whitaker IY. 2008 & Brazil & 55 & 73.7 & - \\
\hline $\begin{array}{l}\text { Sousa RMC, Padilha KG, Nogueira LS, } \\
\text { Miyadahira AMK, Oliveira VCR. } 2009\end{array}$ & Brazil & 600 & $\begin{array}{c}\text { Adults: } 59.9 \\
\text { The elderly: } 64.4 \\
\text { Very old: } 62.4\end{array}$ & - \\
\hline $\begin{array}{l}\text { Padilha KG, Sousa RM, Garcia PC, Bento ST, } \\
\text { Finardi EM, Hatarashi RH. } 2010\end{array}$ & Brazil & 68 & 63.7 & 58.5 to 71.7 \\
\hline Inoue KC, Matsuda LM. 2010. & Brazil & 107 & - & - \\
\hline $\begin{array}{l}\text { Coelho FUA, Queijo AF, Andolhe R, } \\
\text { Gonçalves LA, Padilha KG. } 2011\end{array}$ & Brazil & 100 & 66.6 & - \\
\hline Stafseth SK, Solms D, Bredal IS. 2011 & Norway & 235 & 96.2 & - \\
\hline Inoue KC, Kuroda CM, Matsuda LM. 2011 & Brazil & 100 & 104 & $700-141$ \\
\hline Leite IRL, Silva GRF, Padilha KG. 2012. & Brazil & 66 & 68.1 & 51.5 to 108.3 \\
\hline Panunto MR, Guirardello EB. 2012 & Brazil & 107 & 62.2 & 0 to 153.3 \\
\hline $\begin{array}{l}\text { Queijo AF, Padilha KG, Martins RS, Andolhe } \\
\text { R, Oliveira EM, Barbosa RL et al. } 2013\end{array}$ & Brazil & 100 & 65.1 & - \\
\hline
\end{tabular}

Figure 1 - Distribution of articles according to authors, year of publication, country, sample, average and variation of the Nursing Activities Score 


\section{Discussion}

The publications about the use of the Nursing Activities Score were conducted from the year 2006 on, assuming that a certain period of time was necessary, since its creation in 2002, for the familiarization of the mentioned instrument by the researchers, as well as for its dissemination in the academic and hospital environment.

The results of Nursing Activities Score found point to a high demand for nursing care, bigger than $50 \%$ of professional workload in all the studies analyzed. Thus, a nursing professional could take care entirely of only one patient per work shift. And in the study whose average of Nursing Activities Score was $104 \%$, the professional would not be able to assist only one patient in a complete way in their work shift ${ }^{(14)}$.

Still on the topic of proper measure of the nursing staff in Intensive Care Units, the studies analyzed also made reference to the proportion of professionals and inpatients. The ordinance of the Ministry of Health No. 3432 from August 12, 1998 and the Resolution of the National Health Surveillance Agency RDC No. 26 from May 11, 2012, state that there should be at least one nursing technician for every two beds per work shift ${ }^{(1,15)}$.

The averages of Nursing Activities Score found in six Brazilian studies ${ }^{(4,16-20)}$ were between 65 and $70 \%$. Considering the average obtained and the fact that every professional should have $100 \%$ of their time to provide care to patients, being able to take care of, at most, two patients requiring $50 \%$ of the time each, it is assumed that it would be unfeasible the proportion of one nursing technician for every two patients recommended by the current legislation.

When assessing the Nursing Activities Score as a measure of nursing workload, its applicability per shift and its correspondence with the number of effective nursing staff, it was concluded that both during the shifts as well as in 24 hours the need of Nursing Activities Score was lower than the effective number of professionals who were present. It was found, however, a closer relationship between the need Nursing Activities Score and the average staff in 24 hours (6.4 and 7.1 professionals) than in the shifts (5.2 and 7.5 professionals for the morning; 5.1 and 7.1 professionals for the afternoon; 5.6 and 6.9 professionals for the night) ${ }^{(5)}$.

It was measured up, through the Nursing Activities Score, Nine Equivalents of Nursing Manpower use Score and TISS-28, the nursing workload in a post-cardiac surgery unit. The need for professionals, according to the demand of nursing care, estimated by both the Nursing Activities Score (3.6) as well as the TISS-28 (3.1) or Nine Equivalents of Nursing Manpower use Score (3.0) was lower than what was observed in the unit (4.5). Thus, the proportion of nursing professionals per patient calculated based on the Nursing Activities Score (1.0:1), on TISS-28 (0.8:1) and on Nine Equivalents of Nursing Manpower use Score (0.8:1) was also lower than that observed in this unit (1.2:1). However, it is observed that the relationship that was the closest to the unit's was the Nursing Activities Score ${ }^{(21)}$.

In 2010 a study aiming to analyze the measure of the nursing staff of an adult Intensive Care Unit through the application of the Nursing Activities Score and of the COFEN's Resolution No. 293/2004 pointed a deficit of 12 nursing professionals, which represents a deficiency of $30 \%$ of these professionals ${ }^{(2)}$.

The nursing workload is composed of the time spent by the team to carry out the activities of their responsibility, which are directly or indirectly related to patient's care. These activities can suffer interference of the individual's degree of dependence, of the complexity of the disease, of the characteristics of the institution, of work processes and of the profile of the professionals who compose the team ${ }^{(22)}$. In this sense, the situation is worrying about the measure of the nursing staff found in the studies surveyed, given the high rate of perceived inadequacies, which may compromise the quality and safety of nursing care.

Out of the 18 articles evaluated, six highlighted the items of the Nursing Activities Score which were 
the most $\operatorname{scored}^{(3-5,14,19,23)}$. The items of laboratory investigations and medication (except vasoactive drugs) stood out for appearing in all the articles, what can be justified because they represent commonly adopted practices for hospitalized patients. Other items that were repeated were: support and care from family members for about one hour in any shift, quantitative measure of urinary output and accomplishment of hygiene procedures

Another aspect addressed in the studies was the comparison of the measure of nursing workload performed through the Nursing Activities Score with other scales, such as the TISS-28 and the Nine Equivalents of Nursing Manpower use Score. In the research conducted in Spain in order to verify the correlation between measures of workload conducted through the Nursing Activities Score and the Nine Equivalents of Nursing Manpower use Score revealed that the Nursing Activities Score reflects a more appropriate measure of nursing workload when compared to the Nine Equivalents of Nursing Manpower use Score ${ }^{(24)}$.

When comparing the nursing workload in a Intensive Care Unit of postoperative cardiac surgery defined by the Nursing Activities Score, TISS-28 and Nine Equivalents of Nursing Manpower use Score, it was concluded that due to the foundations of the Nursing Activities Score in specific activities of the nursing staff in Intensive Care Units, it is more appropriate to estimate the amount of nurses in relation to TISS-28 and Nine Equivalents of Nursing Manpower use Score ${ }^{(21)}$. A study in Norway with the aim of comparing the nursing workload obtained through the Nine Equivalents of Nursing Manpower use Score and the Nursing Activities Score also demonstrated better results using the Nursing Activities Score ${ }^{(25)}$.

It was also noticed the concern of the researchers to correlate the Nursing Activities Score with clinical and demographic variables such as gender, age, length of stay, severity index (Simplified Acute Physiologic Score), index of organ dysfunction (Logistic Organ Dysfunction System) among others.
Regarding the variables age and sex, no positive results were found of the association with the Nursing Activities Score. The study that compared the nursing workload required by adults, the elderly and very old patients revealed that age did not significantly improve the workload given to patients admitted to the Intensive Care Unit, as well as gender ${ }^{(26)}$. When one compared three age groups of the elderly, one from 60 to 69 years old, another from 70 to 79 years old and the third from 80 years old on, it was observed a similar Nursing Activities Score among them (72.4\%, $74.3 \%$ and $71.9 \%$, respectively) ${ }^{(17)}$.

By comparing the averages of the Nursing Activities Score with the variables sex, length of stay, type of admission and age group, it was found through a univariate analysis that the only variable related to nursing workload of significant value was the type of admission, showing that surgical patients required more time of nursing care compared to those with acute medical conditions, with Nursing Activities Score of 83.5 and $72.1(\mathrm{p}=0.036)$, respectively ${ }^{(17)}$. Another association of increase in the nursing workload with surgical patients was reported in a study that demonstrated that surgical patients were nearly three times more likely (2.79) to demand high nursing workload in the first 24 hours of hospitalization than those undergoing medical therapy ${ }^{(14)}$.

A study aiming to analyze the nursing workload and the factors associated with it, in the first day of patients' hospitalization in the Intensive Care Unit concluded that the permanence time was the only variable significantly associated with nursing workload $(\mathrm{p}=0.01)^{(4)}$.

When the association between the Nursing Activities Score and the patients' variables were explored, it was found that high points in the Nursing Activities Score were associated with mortality, organ dysfunction (Logistic Organ Dysfunction System), severity of patients' illnesses, and especially therapeutic interventions in the Intensive Care Unit ${ }^{(27)}$. Additional studies have confirmed the association between higher points of the Nursing Activities Score 
with mortality, disease severity (Simplified Acute Physiologic Score II), the Logistic Organ Dysfunction System and the length of stay ${ }^{(20,28)}$.

It is noticed that the correlation between the Nursing Activities Score and some clinical variables is still undefined in scientific literature, not allowing a consensus on what variables are actually associated with the results of the Nursing Activities Score. By analyzing the performance of the Nursing Activities Score for the prospective measure of the nursing workload in the Intensive Care Unit and by comparing the values of the Nursing Activities Score obtained in the prospective and retrospective application of the instrument. As a result, the research has shown that the prospective Nursing Activities Score performed well to measure the nursing workload in the Intensive Care Units, being possible its application for the distribution of nursing professionals during a period of work, based on patients' care needs ${ }^{(29)}$.

\section{Final Considerations}

The instrument Nursing Activities Score was used differently according to the proposed objectives, namely: to obtain the average Nursing Activities Score; observation of the highest scored items of the instrument; application to different age groups; correlation with severity indexes and other measure tools of the nursing staff.

The studies showed a high average of Nursing Activities Score, bigger than $50 \%$ in all the studies reviewed, being inconsistent with that recommended by the Ministry of Health. In this sense, it is presupposed that the measure of the nursing staff in Intensive Care Units is inadequate for the provision of quality care aiming at the patients' security.

When compared to other measure instruments of nursing workload, the Nursing Activities Score was presented as the most appropriate for estimating the amount of nurses in adult Intensive Care Units. The correlation between the Nursing Activities Score and demographic and clinical variables are not well defined in the research results, presenting variations in the studies analyzed.

The Nursing Activities Score is a relatively new instrument, which has a great potential for expansion due to the good results with its use so far. Thus, it is suggested that further research is undertaken to consolidate this valuable instrument to measure nursing workload.

\section{Collaborations}

Ferreira PC, Machado RC, Victor AF, Lira ALBC and Martins QCS contributed to the design, data analysis and interpretation and writing of the article.

\section{References}

1. Ministério da Saúde (BR). Agência Nacional de Vigilância Sanitária. Resolução № 7, de 24 de fevereiro de 2010. Dispõe sobre os requisitos mínimos para funcionamento de Unidades de Terapia Intensiva e dá outras providências. Diário Oficial da União, Brasília, 25 fev. 2010. Seção 1, p.48-58.

2. Inoue KC, Matsuda LM. Sizing the nursing staff in an Intensive Care Unit for Adults. Acta Paul Enferm. 2010; 23(3):379-84.

3. Panunto MR, Guirardello EB. Nursing workload in an intensive care unit of a teaching hospital. Acta Paul Enferm. 2012; 25(1):96-101.

4. Gonçalves LA, Padilha KG. Fatores associados à carga de trabalho de enfermagem em Unidade de Terapia Intensiva. Rev Esc Enferm USP. 2007; 41(4):645-52.

5. Conishi RM, Gaidzinski RR. Nursing Activities Score (NAS) como instrumento para medir carga de trabalho de enfermagem em UTI adulto. Rev Esc Enferm USP. 2007; 41(3):346-54.

6. Cullen D, Civetta J, Briggs B, Ferrara L. Therapeutic Intervention Scoring System (TISS): a method for quantitative comparison of patient care. Crit Care Med. 1974;2(2):57-60.

7. Keene A, Cullen D. Therapeutic intervention scoring system: update 1983. Crit Care Med. 1983;11(1):1-3. 
8. Miranda D, Rijk A, Schaufeli W. Simplified Therapeutic Intervencion Scoring System: theTISS-28 itens-results from a multicenter study. Crit Care Med. 1996;24(1):64-73.

9. Miranda RD, Nap R, Rijk A, Schaufeli W, Iapichino G. Nursing activities score. Crit Care Med. 2003; 31(2):374-82.

10. Souza MT, Silva MD, Carvalho R. Revisão integrativa: o que é e como fazer. Einstein. 2010; 8(1):102-6.

11. Queijo AF, Padilha GK. Nursing Activities Score (NAS): adaptação transcultural e validação para a língua portuguesa. Rev Esc Enferm USP. 2009; 43(Esp):1018-25.

12. Arias-Rivera $S$, Sánchez-Sánchez MM, Fraile-Gamo MP, Patiño-Freire S, Pinto-Rodríguez V, CondeAlonso MP et al. Adaptación transcultural al castellano del Nursing Activities Score. Enferm Intensiva. 2013; 24(1):12-22.

13. Ursi ES, Galvão CM. Prevenção de lesões de pele no perioperatório: revisão integrativa da literatura. Rev Latino-Am Enfermagem. 2006; 14(1):124-31.

14. Inoue KC, Kuroda CM, Matsuda LM. Nursing Activities Score (NAS): carga de trabalho de enfermagem em UTI e fatores associados. Ciênc Cuid Saúde. 2011; 10(1):134-40.

15. Ministério da Saúde (BR). Agência Nacional de Vigilância Sanitária. Resolução № 26, de 11 de maio de 2012. Altera a Resolução RDC no. 07, de 24 de fevereiro de 2010, que dispõe sobre os requisitos mínimos para funcionamento de Unidades de Terapia Intensiva e dá outras providências. Diário Oficial da União, Brasília, 14 maio. 2012. Seção 1, p.170.

16. Gonçalves LA, Garcia PC, Toffoleto MC, Telles SC, Padilha KG. Necessidades de cuidados de enfermagem em terapia intensiva: evolução diária dos pacientes segundo o Nursing Activities Score (NAS). Rev Bras Enferm. 2006; 59(1):56-60.

17. Sousa CR, Gonçalves LA, Toffoleto MC, Leão K, Padilha KG. Predictors of nursing workload in elderly patients admitted to intensive care units. Rev Latino-am Enfermagem. 2008; 16(2):218-23.
18. Padilha KG, Sousa RM, Garcia PC, Bento ST, Finardi EM, Hatarashi RH. Nursing workload and staff allocation in an intensive care unit: a pilot study according Nursing Activities Score (NAS). Intensive Crit Care Nurs. 2010; 26(2):108-13.

19. Leite IRL, Silva GRF, Padilha KG. Nursing Activities Score e demanda de trabalho de enfermagem em terapia intensiva. Acta Paul Enferm. 2012; 25(6):837-43.

20. Queijo AF, Padilha KG, Martins RS, Andolhe R, Oliveira EM, Barbosa RL, et al. Nursing workload in neurological intensive care units: cross-sectional study. Intensive Crit Care Nurs. 2013; (29):112-6.

21. Ducci AJ, Zanei SSV, Whitaker IY. Carga de trabalho de enfermagem para quantificar proporção profissional de enfermagem/paciente em UTI cardiológica. Rev Esc Enferm USP. 2008; 42(4):673-80.

22. Girardello DTF, Nicola AL, Fernandes LM. Nursing care: hours required for critical patient's care. Rev Rene. 2013; 14(6):1084-91.

23. Ciampone JT, Gonçalves LA, Maia FOM, Padilha KG. Necessidade de cuidados de enfermagem e intervenções terapêuticas em UTI: estudo comparativo entre pacientes idosos e não idosos. Acta Paul Enferm. 2006; 19(1):28-35

24. Adell AB, Campos RA, Bou MY, Bellmunt JQ, García CG, Canuto MS et al. Cargas de trabajo asistencial em pacientes críticos. Estudio comparativo NEMS frente a NAS. Enferm Intensiva. 2006; 17(2):6777.

25. Stafseth SK, Solms D, Bredal IS. The characterisation of workloads and nursing staff allocation in intensive care units: a descriptive study using the Nursing Activities Score for the first time in Norway. Int Crit Care Nurs. 2011; (27):290-4.

26. Sousa RMC, Padilha KG, Nogueira LS, Miyadahira AMK, Oliveira VCR. Carga de trabalho de enfermagem requerida por adultos, idosos e muito idosos em Unidade de Terapia Intensiva. Rev Esc Enferm USP. 2009; 43(n. esp. 2):1284-91. 
27. Padilha KG, Sousa RMC, Queijo AF, Mendes AM, Miranda DR. Nursing Activities Score in the intensive care unit: analysis of the related factors. Intensive Crit Care Nurs. 2008; 24(3):197-204.

28. Coelho FUA, Queijo AF, Andolhe R, Gonçalves LA, Padilha KG. Carga de trabalho de enfermagem em unidade de terapia intensiva de cardiologia e fatores associados. Texto Contexto Enferm. 2011; 20(4):735-41.
29. Ducci AJ, Padilha KG. Nursing activities score: estudo comparativo da aplicação retrospectiva e prospectiva em unidade de terapia intensiva. Acta Paul Enferm. 2008; 21(4):581-7. 